http://dx.doi.org/10.11646/phytotaxa.150.1.3

\title{
Seed-coat anatomy and microsculpturing of the genus Erysimum (Brassicaceae) in Northeast of Iran
}

\author{
SOMAYE GHAEMPANAH ${ }^{1}$, HAMID EJTEHADI $^{1}$, JAMIL VAEZI $^{* 2} \&$ MOHAMMAD FARSI $^{3}$ \\ ${ }^{I}$ Department of Biology, Faculty of Science, Ferdowsi University of Mashhad, Mashhad, Iran \\ ${ }^{2}$ Department of Biology, Faculty of Science, Shahid Chamran University of Ahvaz, Ahvaz, Iran \\ ${ }^{3}$ Research Center for Plant Sciences, Ferdowsi University of Mashhad, Mashhad, Iran \\ "Corresponding Author: J.vaezi@scu.ac.ir
}

\begin{abstract}
In order to examine the systematic application of seed-coat characters in Erysimum (Brassicaceae) distributed in Northeast of Iran (Khorassan provinces), the seeds of nine species (14 populations) were examined using the light microscope (LM) and the scanning electron microscope (SEM). According to results of the LM, diagnostic characters at the specific level are seed shape, wing width, epidermal cell-wall shape, and seed-surface sculpture. The SEM investigation at high magnifications reveals that seven types of seed-surface sculpture pattern are distinguishable, including 1) reticulate, the basic type; 2) ocellate; 3) papillate; 4) reticulate-papillate; 5) scalariform; 6) ribbed; and 7) reticulate-ocellate. The seed coat typically consists of four layers, including the epidermis layer, the subepidermis layer, the sclerotic (or palisade) layer, and the parenchymatous layer. Some of the layers may be absent in some species. Finally, an identification key to the investigated taxa is provided based on the seed-coat characters used in this research.
\end{abstract}

Key words: Erysimeae, Erysimum, Khorassan, seed-surface sculpture, taxonomy

\section{Introduction}

The genus Erysimum Linnaeus (1753a: 660) (Brassicaceae) which belongs to the unigeneric tribe Erysimeae consists of more than 200 species worldwide (German \& Al-Shehbaz 2008, Couvreur et al. 2010, Al-Shehbaz 2012).

Generally, members of the family Brassicaceae have small seeds with mostly less than $4 \mathrm{~mm}$ long (AlShehbaz 1986). Seeds can have wings or not; when present, the wings may surround the entire seed or limited to one or both ends. Seed sculpture may be smooth, reticulate, scalariform, ribbed, papillate, ocellate, or foveolate that can be useful for identifying taxa (Vaughan \& Whitehouse 1971). The seeds vary in color and may be white (Pringlea W.Anderson ex Hook.f. (1845: 239)), yellow, orange, and green to brown or black (Appel \& Al-Shehbaz 2003). In Brassicaceae, micro- and macroscopic characters of seeds are useful to determine the taxonomic boundaries among taxa, especially genera and species, and to realize their relationships (Zhang 2003, Tantawy et al. 2004). Based on previous studies (e.g. Davis \& Heywood 1963, Latowski 1975), in this family, traits related to seeds, together with features of the fruit, nectarines, and type of hairs are very efficient and reliable for divisions at the generic and tribal levels. Many studies on the seed coat in this family have been done on the taxa with economic value (e.g. Brassica Linnaeus (1753a: 666), Sinapis Linnaeus (1753a: 668), and Raphanus Linnaeus (1753a: 669)) (e.g. Barton 1967, Mulligan \& Bailey 1976).

The importance of scanning electron microscope (SEM) in solving of systematic problems has been considered by Heywood (1971). In Brassicaceae, exo- and endomorphic traits of seeds have been studied by many people such as Fayed and El-Naggar (1988, 1996), El-Naggar \& El-Hadidi (1998), and Abdel Khalik (2002). In addition, the ultrastructural pattern acts as a reliable criterion for study of phenetic relationships and classification problems in the family (Koul \& Ranjna 2000, Moazzeni et al. 2007). 
4. Seeds kidney-shaped; epidermal cells 4-6 sided; periclinal wall convex; sculpture pattern ribbed; seed coat without subepidermal layer in cross section

E. griffithianum Boiss.

- Seeds elliptic-oblong; epidermal cells rectangular; periclinal wall flat to convex; sculpture pattern scalariform; seed coat with one layer of subepidermal cells in cross section E. repandum L.

5. Seeds kidney-shaped; seed-surface sculpture smooth or ocellate; sculpture pattern reticular or reticular-ocellate; epidermal cell with osteosclereids

- Seeds elliptic-oblong or ovate-linear; seed-surface sculpture papillate or folded; sculpture pattern papillate, reticular-papillate or scalariform; epidermal cell without osteosclereids

6. Periclinal wall convex; seed-surface sculpture smooth; sculpture pattern reticular; seed coat with 6 layers in cross section; subepidermis with 4 layers ..... E. ischnostylum Freyn and Sint.

- Periclinal wall concave; seed-surface sculpture ocellate; sculpture pattern reticular-ocellate; seed coat with 5 layers in cross section; subepidermis with 3 layers. E. stocksianum (Boiss.) Boiss.

7. Seeds elliptic-oblong; seed surface with cellular arrangement; periclinal wall flat to concave ...............................8

- Seeds ovate-linear; seed surface without cellular arrangement; periclinal wall convex

Ep..................................................................................................... crassipes Fisch. and C.A.Mey. subepidermis layer with collenchymal cells; seed coat with epidermal layer in cross section.

E. crassicaule (Boiss.) Boiss.

Epidermal cells rectangular; anticlinl wall sunken; seed-surface sculpture folded; sculpture pattern scalariform; subepidermis layer without collenchymal cells; seed coat without epidermal layer in cross section E. $s p$.

\section{Acknowledgements}

The authors thank A. A. Basiri (Plant Systematic Laboratory Technician of Faculty of Sciences, Ferdowsi University of Mashhad) for providing plant material of several species. The authors also thank M. R. Joharchi in Research Centre for Plant Sciences (FUMH) and H. Moazzeni for their indispensable helps. This work is a part of M.Sc. thesis of the first author.

\section{References}

Abdel Khalik, K.N.E. (2002) Biosystematic studies on Brassicaceae (Cruciferae) in Egypt. Ph.D. Dissertation. Wageningen University, Netherlands, $278 \mathrm{pp}$.

Abdel Khalik, K.N.E. \& Maesen L.J.G. van der. (2002) Seed morphology of some tribes of Brassicaceae (Implication for taxonomy and species identification for the flora of Egypt). Blumea 47: 363-383.

Akhani, H. (2003) Notes on the flora of Iran: 4. Two new records and synopsis of the new data on Iranian Cruciferae since Flora Iranica. Candollea 58: 369-385.

Al-Shehbaz, I.A. (1986) The genera of Lepidieae (Cruciferae; Brassicaceae) in southeastern United States. Journal of Arnold Arboretum 67: 265-311.

Al-Shehbaz, I.A. (2012) A generic and tribal synopsis of the Brassicaceae (Cruciferae). Taxon 61: 931-954.

Appel, O. \& Al-Shehbaz, I.A. (2003) Cruciferae. In: Kubitzki, K. \& Bayer, C. (eds.) The Families and Genera of Vascular Plants. Springer-verlag, Germany, pp. 57-174.

Barthlott, W. (1981) Epidermal and seed surface characters of plants: systematic applicability and some evolutionary aspects. Nordic Journal of Botany 1: 345-355. http://dx.doi.org/10.1111/j.1756-1051.1981.tb00704.x

Barton, L.V. (1967) Bibliography of Seeds. Columbia University Press, New York, 858 pp.

Boissier, P.E. (1842) Plantae aucherianae orientales enumeratae, cum novarum specierum description. Annales des Sciences Naturelles, $2^{\mathrm{e}}$ serie, tome 17: 45-91.

Boissier, P.E. (1854) Erysimum griffithianum. Diagnoses Plantarum Orientalium Novarum, 3(1), 122 pp.

Boissier, P.E. (1854) Cheiranthus stocksianus. Diagnoses Plantarum Orientalium Novarum, ser 2, 1, 120 pp.

Boissier, P.E. (1867) Flora Orientalis, Vol. 1, Geneva, 1017 pp.

Botschantsev, V.P., Kurbanov, D.K. \& Gudkova, E.P. (1983) Three new plant species from Turkmenia. Botanicheskii Zhurnal 68: 236-238.

Bouman, F. (1975) Integument initiation and testa development in some Cruciferae. Botanical Journal of the Linnean Society 70: 213-299. 
http://dx.doi.org/10.1111/j.1095-8339.1975.tb01646.x

Busch, N.A. (1939) Cruciferae. In: Komarov, V.L. (ed.) Fl. USSR. vol. 8. Izdatel'stvo Akademii Nauk SSSR, Moscow, Leningrad, $692 \mathrm{pp}$.

Couvreur, T.L.P., Franzke, A., Al-Shehbaz, I.A., Bakker, F.T., Koch, M.A. \& Mummenhoff, K. (2010) Molecular phylogenetics, temporal diversification, and principles of evolution in the Mustard family (Brassicaceae). Molecular Biology and Evolution 27(1): 55-71. http://dx.doi.org/10.1093/molbev/msp202

Davis, P.H. \& Heywood, V.H. (1963) Principles of angiosperm taxonomy. Oliver and Boyd, Edinburgh and London, 556 pp.

El-Naggar, S.M. \& El-Hadidi, M.N. (1998) The tribe Alysseae Hayek (Brassicaceae) in Egypt. Journal of Union of Arab Biologists 6: 501-20.

Fayed, A.A. \& El-Naggar, S.M. (1988) Taxonomic studies on Cruciferae in Egypt. 2. Taxonomic significance of the seed sculpture in species of tribe Brassiceae. Tackholmia 11: 87-95.

Fayed, A.A. \& El-Naggar, S.M. (1996) Taxonomic studies on Cruciferae in Egypt. 4. Seed morphology and taxonomy of the Egyptian species of Lepidieae. Bulletin of the Faculty of Science, Assiut University 25: 43-50.

Fischer, F.E.L. \& Meyer, C.A. (1836) Erysimum crassipes. Linnaea, Ein Journal für die Botanik in ihrem ganzen umfange, Herausgegeben von D.F.L. von Schlechtendal, 10 (Lit), 220 pp.

Freyn, J. (1903) Plantae ex Asia media. Bulletin de l'Herbier Boissier. $2^{\text {me }}$ série. T. III. Geneva, 1204 pp.

German, D.A. \& Al-Shehbaz, I.A. (2008) Five Additional Tribes (Aphragmeae, Biscutelleae, Calepineae, Conringieae, and Erysimeae) in the Brassicaceae (Cruciferae). Harvard papers in Botany 13: 165-170. http://dx.doi.org/10.3100/1043-4534(2008)13[165:fatabc]2.0.co;2

Ghaempanah, S., Vaezi, J., Ejtehadi, H., Farsi, M. \& Joharchi, M.R. (2012) Morphometric study of species Erysimum L. (Brassicaceae) in the provinces of North, Razavi and South Khorassan [in Persian with summary in English]. Journal of Taxonomy and Biosystematics 10: 77-94.

Heywood, V.H. (1971) Scanning electron microscopy. Systematic and evolutionary applications. Academic Press, London, $331 \mathrm{pp}$.

Hooker, J.D. (1845) Flora Antarctica. Botany of the Antarctic voyage. Vol. 2, Reeve Brothers, London, 574 pp.

Jonsell, B. (1986) A monograph of Farsetia (Cruciferae). Systematic Botany 25: 1-106.

Kasem, W.T., Ghareeb, A. \& Marwa, E. (2011) Seed Morphology and Seed Coat Sculpturing of 32 Taxa of Family Brassicaceae. Journal of American Science 7: 166-178.

Korshinski, S.L. (1898) Erysimum verrucosum var. badghisi. Izvestiya Imperatorskoj Akademii Nauk, ser. 5, 9, 564 pp.

Koul, K.K. \& Ranjna, N. (2000) Seed coat microsculpturing in Brassica and allied genera (subtribes Brassicinae, Raphaninae, Moricandiinae). Annals of Botany 86: 385-97.

Latowski, K. (1975) Morphology and anatomy of fruits and seeds of the Middle European Erysimum L. Species [in Polish with summary in English]. Monographiae Botanicae 49: 5-77.

Linnaeus, C. (1753a) Species Plantarum. Vol. 2. Stockholm: Impensis Laurentii Salvii, Holmiae, 1200 pp.

Linnaeus, C. (1753b) Demonstrations Plantarum in Horto Upsaliensi. Proponit Johannes Christ. Hojer, etc. Upsaliae [tax. nov.], 27 pp.

Maciejewska-Rutkowska, I., Bednorz, L. \& Fujiki, T. (2007) SEM observations of pollen grains, fruit and seeds of the pieniny mountain (South Polland) endemic species Erysimum piennicum (Zapal.) Pawl. (Brassicaceae). Acta Societatis Botanicorum Poloniae 76: 127-132. http://dx.doi.org/10.5586/asbp.2007.016

Moazzeni, H., Zarre, Sh., Al-Shehbaz, I.A. \& Mummenhoff, K. (2007) Seed-coat microsculpturing and its systematic application in Isatis (Brassicaceae) and allied genera in Iran. Flora 202: 447-454. http://dx.doi.org/10.1016/j.flora.2006.10.004

Mulligan, G.A. \& Bailey, L.G. (1976) Seed coats of some Brassica and Sinapis weedy and cultivated in Canada. Economic Botany 30(2): 143-148. http://dx.doi.org/10.1007/bf02862959

Murley, M.R. (1951) Seeds of the Cruciferae of Northeastern North America. The American Midland Naturalist Journal 46: $1-81$. http://dx.doi.org/10.2307/2421948

Jafri, S.M.H. (1973) Erysimum L. In: Nasir, E. \& Ali, S.I. (eds.) Flora of West Pakistan. Ferozsons, Karachi, 55: 232242.

Polatschek, A. \& Rechinger, K.H. (1968) Erysimum (Cruciferae). In: Rechinger, K.H. (eds.) Flora Iranica. Akademische Druck - u. Verlagsanstalt, Graz, 57: 285-305.

Polatschek, A. (2011) Revision der Gattung Erysimum (Cruciferae), Teil 2: Georgien, Armenien, Azerbaidzan, Türkei, Syrien, Libanon, Israel, Jordanien, Irak, Iran, Afghanistan. Annalen des Naturhistorischeh Museums in Wien, B, 112: $369-497$.

Rohlf, F.J. (2000) NTsys-pc, Numerical taxonomy and multivariate analysis system. Ver. 2.0. Exeter Software Pub. (Ltd.) 
New York.

Rollins, R.C. (1963) The evolution and systematic of Leavenwortia (Cruciferae). Contributions from the Gray Herbarium of Harvard University 192: 3-98.

Tantawy, M.E., Khalifa, S.F., Hassan, S.A. \& Al-Rabiai, G.T. (2004) Seed Exomorphic Characters of Some Brassicaceae (LM and SEM Study). International Journal of Agriculture and Biology 5: 821-830.

TerBraak, C.J.F. \& Smilauer, P. (2002) CANOCO Reference manual and user's guide to Canoco for Windows: Software for Canonical Community Ordination (version 4). Microcomputer Power, Ithaca.

The plant list. (2010) version 1. Published on the Internet; http://www.theplantlist.org/ (accessed 1st January).

Vaughan, J.G. \& Whitehouse, J.M. (1971) Seed structure and the taxonomy of the Cruciferae. Botanical Journal of the Linnean Society 64: 383-409. http://dx.doi.org/10.1111/j.1095-8339.1971.tb02153.x

Vaughan, J.G., Phelan, J.R. \& Denford, K.E. (1976) Seed studies in the Cruciferae. In: Vaughan, J.G., Macleod, A.J. \& Jones, B.M.G. (eds.) The biology and chemistry of the Cruciferae. Academic Press, London, pp. 119-144

Zhang, Y.-H. (2003) Delimitation and revision of Hilliella and Yinshania (Brassicaceae). Acta hytotaxonomica Sinica 41 : 305-349.

Zapalowicz, H. (1913) Revue critique de la flore Galicie XXVII. Bulletin International de l'Academie des Sciences de Cracovie, ser. B, nr. 3, 446 pp. 